\title{
Twelve Years a Slave and the 'Unthinkability' of Enslaved Autobiography
}

\author{
Sean M. Kelley
}

\section{University of Essex}

When Barack Obama was elected president in 2008, some pundits argued that it heralded a new 'post-racial' era. To say that was wishful thinking would be a gross understatement. But it is quite clear that in the late 2000s and early 2010s popular interest in the history of slavery and race in the United States was on the rise. In the eighteen months preceding the release of director Steve McQueen's Twelve Years a Slave, the New York Times ran over two hundred articles focused on American and New World slavery, on topics ranging from First Lady Michelle Obama's genealogy to Walmart's plan to build a superstore on a slave burial ground in Alabama. Scholarly interest was also on the rise, invigorated by a new generation of historians concerned with the role of slavery in the making of American capitalism. But perhaps most importantly, McQueen's film was released eighteen months after the shooting of the unarmed seventeen year-old Trayvon Martin attracted international attention to the issue of white violence toward African Americans. The anti-racist organization Black Lives Matter was founded only weeks before the film appeared. The release of McQueen's film in August 2013 was therefore quite timely, its tone and content very much in step with both popular interests and academic trends. Twelve Years a Slave went on to win three Academy Awards, including Best Picture, and a host of other honours, including Best Picture at the Golden Globes and Best Film from BAFTA.

Based on Solomon Northup's classic 1853 slave narrative of the same name, the film almost took a radically different form. As Steve McQueen tells it, the idea for filming a story about a free northern man being kidnapped into slavery in the Deep South emerged before its 
producers became acquainted with Northup's narrative. He actually worked on the concept for some time with screenwriter John Ridley but reached a dead end. It was only then that McQueen's wife suggested working from historical documents, which led to his discovery of Northup. 'I was pretty upset with myself that I didn't know this book,' he later said, 'and slowly but surely I realized that most people, in fact all the people I knew, did not know this book' (Chiwetel Ejiofor and Steve McQueen, interview by Terry Gross, Fresh Air, NPR, October 24, 2013).

McQueen can certainly be forgiven for not knowing of Northup's narrative-relatively few non-academics did prior to the making of the film. But his confessed inability to conceive of finding an actual autobiography on which to base his film calls to mind Michel Rolph Trouillot's observation on the Haitian Revolution as an event that was 'unthinkable even as it happened'. ${ }^{1}$ After all, autobiography and biography presume personhood, while slavery, in its abstract logic if not in actual practice, denied the personhood of its subjects. This assumption has led to what some historians have called a 'chain of silence' regarding slavery, or the invisibility of enslaved people as historical subjects, worsened by the persistence of racism. McQueen's admission speaks to a host of interrelated issues concerning black autobiography and biography from the era of slavery, issues that in many respects carried over to the film. These include the reliability and veracity of the slave testimony and the related question of authorial voice. So while McQueen's version of Twelve Years a Slave is a mostly faithful adaptation of Northup's original narrative, it does not grapple with some of the more difficult issues surrounding slave autobiography. McQueen is not to be faulted for this. Commercial cinema should not be judged by academic criteria, and addressing these issues would have resulted in a very different film. But that is actually the point: it is difficult to reconcile the divergent imperatives of commercial feature film and the 
complex politics of slave autobiography. McQueen did about as well as can be expected given the system in which he worked.

Twelve Years a Slave was only the latest in a long tradition of cinematic representations of slavery dating back to the dawn of filmed story-telling, with the earliest known depiction being a 1903 adaptation of Harriet Beecher Stowe's Uncle Tom's Cabin. This film established a pattern in which many cinematic depictions of slavery were taken from fiction. Indeed, some of these rank among the most popular films of all time, not coincidentally because they often played to the worst racial stereotypes. Thomas Dixon's novel The Clansman (1903) became D.W. Griffith's Birth of a Nation (1915), while Margaret Mitchell's Gone with the Wind (1935) became Victor Fleming's 1939 cinematic spectacular of the same title. ${ }^{2}$

But apart from obvious differences of tone and interpretation, Twelve Years a Slave was distinguished from most of its predecessors in that it was drawn not only from historical sources, but that it was based on an autobiographical narrative. This reluctance to take a biographical approach to slavery has not been limited to filmmakers. African American biography has always been a politically fraught topic. Slave narratives in particular were hotly contested texts prior to emancipation, since they highlighted individuality and personhood in the face of a dehumanizing institution. Slavery's defenders often sowed doubts regarding their authenticity, which as we will see carried over into modern scholarship. In fact, until relatively recently, even most historians believed that recovering the life stories of enslaved individuals was largely impossible due to the lack of authentic sources written from the point of view of the enslaved. The 'true' story of slavery, it was thought, could only be told in the aggregate; individual experiences were unrecoverable. This is surely one reason why so many earlier cinematic treatments turned to fiction for inspiration. The historical record, it was believed, simply did not permit access to the kind of interiority that 
makes for compelling film. Even Roots, the 1977 blockbuster television mini-series, which at the time was presented as the fruit of heroic genealogical research by Alex Haley, was later admitted to be 'faction,' a combination of 'fact' and 'fiction.' Even for Haley, it seems, the possibility of doing African biography was unthinkable. ${ }^{3}$

Contrary to popular perception, much more auto- and biographical testimony survives than most people realise, in court depositions, missionary records, and other diverse sources. And of course, a significant body of autobiographical material survives in what are usually called the 'slave narratives', which blossomed as a literary genre in the late eighteenth and early nineteenth centuries. In the larger context of Atlantic slavery, these canonical slave narratives are almost unique, limited for the most part to the Anglo-American sphere. Almost no such texts were produced in Latin America or in the many other locales where Atlantic slavery flourished, though a great deal of autobiographical testimony survives for these in forms other than the classic 'slave narrative'. Adopting the strictest definition of 'slave narrative', there are anywhere between about 110 and 120 canonical narratives, a figure that does not include the 2,500 of the narratives collected by the Federal Writers' Project in the 1930s or the thousands of incidental, fragmentary testimonies embedded within other types of records scattered in archives around the Atlantic, from Britain to Brazil. ${ }^{4}$

Most scholars of the canonical slave narrative suggest that it emerged in the AngloAmerican world during the eighteenth century with the publication of Briton Hammon's $A$ Narrative of the Uncommon Sufferings (1760), Ottobah Cugoano's Thoughts and Sentiments (1787), and Gustavus Vassa's Interesting Narrative (1789)..$^{5}$ Other autobiographical and biographical texts by Africans and African Americans predate these, but did not embrace what would eventually become the defining features of the genre. Above all, slave narratives were part of the antislavery movement, condemning slavery and asserting black equality. The authors were quite open about their politics. Both Vassa and Cugoano were active in the early 
effort to abolish the transatlantic slave trade, and their narratives were deliberately crafted as a rebuttal to proslavery arguments. The texts themselves, of course, countered the suggestion that economic self-interest led slave traders and slave owners to treat enslaved people with kindness by offering examples of brutality and corruption. But in addition to the images of slavery offered in the texts, the very existence of books like Vassa's, written in elegant English prose and salted with Biblical and classical references, stood as an implicit refutation of African savagery. It was no coincidence that both Cugoano and Vassa proudly listed themselves as the author, with the title of Vassa's Interesting Narrative adding emphasis by including the epigram 'by himself'. The act of producing black autobiography was therefore always political, an affirmation of the author's humanity in the face of slavery's dehumanizing tendencies and a powerful refutation of black cultural and intellectual inferiority.

While the early focus of the antislavery movement (and consequently, of many narratives) had been the transatlantic slave trade, abolition (by Britain in 1807 and by the United States in 1808) brought a shift in the narratives' focus to the institution of slavery itself. In contrast with eighteenth-century authors, most nineteenth-century authors had been born in the New World. This brought an Americanization of a different sort, a shift away from a concern with the British colonial world and toward a focus on the United States. Despite the fact that slavery persisted in the British Empire until 1833 (replaced by 'Apprenticeship' until 1838), fewer than a half-dozen British narratives were published. In contrast, in the United States, some 55 or so narratives were published between 1800 and the end of slavery in $1865 .^{6}$ This 'golden' age saw the maturation of the slave narrative as a genre, with its many themes fully elaborated. These included the 'kind' slaveowner whose paternalism was eventually exposed as illusory through financial trouble or other means; slaves who had been damaged by slavery, rendered ignorant or emotionally stunted; the 
vulnerability of enslaved women, particularly young and attractive ones, to the master's sexual predations; the hollowness and hypocrisy of the master's Christianity; and the narrator's discovery of freedom, which often arrived with and through literacy. There was a gendered dimension to the narratives as well, with most being written by men. Several of these included an episode of violent resistance to a slave owner or an overseer, a moment when the protagonist asserts his personhood by fighting back, demonstrating, in the words of Frederick Douglass, 'how a slave was made a man'. ${ }^{7}$

What made the slave narratives so powerful was their perceived authenticity. It was one thing to hear about the horrors of slavery from white abolitionists, some of whom had never witnessed Southern slavery, but another thing entirely to hear from those who had experienced it first-hand. It was the narratives' 'true' quality that led northerners to buy the books by the thousands and to turn out to hear some of the more famous authors recount their experiences in theatres and athenaeums. Slave owners and their apologists understood that the narratives' power lay in their veracity and consequently made it a target of attack. This usually took two one of two forms. The first was to charge that the narrator simply lied. Some narratives were picked apart by proslavery activists and revealed to contain errors. In at least one instance, this led to an embarrassing retraction by the narrative's editor. Authors and publishers guarded against charges of this kind by including as much specific detail as possible-names, places, distinctive events—as well as third-party testimony to the truth of the narrator's claims, and sometimes even legal documentation. Revealing so much detail was always a difficult decision, however, since naming names, especially those of collaborators, could easily put people in legal or physical danger. All of this back and forth, and the decision to include many or few details, in the end speaks to the importance of the perceived veracity and truth of the slave narratives as one of the main battlegrounds in the fight over slavery. 
The second line of the proslavery attack also spoke to veracity but focused specifically on authorship, charging that the narratives were the product of interactions between abolitionist editors and illiterate, ignorant former slaves, scarcely capable of understanding what was being written in their name. This was in many respects a more viable attack than simply denouncing the author as a liar. Most (though hardly all) enslaved people were illiterate, so editors and interlocutors of some kind often were involved in crafting the narratives. They are, as modern scholars emphasise, hybrid, multi-vocal texts. Some editors, moreover, rendered former slaves' experiences in florid Victorian prose, which tended to highlight the narratives' collaborative nature. Authors attempted to head such charges off by stressing that the narrative was a true rendering of events as presented by the narrator. The preface to Charles Ball's (composed by Isaac Fisher, who actually referred to himself as 'the author') was typical in asserting that 'The narrative is taken from the mouth of the adventurer himself; and if the copy does not retain the identical words of the original, the sense and import, at least, are faithfully preserved'. A strict adherence to 'the facts' was the coin of the realm. Once more, Isaac Fisher on Charles Ball: 'Many of his opinions have been cautiously omitted, or carefully suppressed, as being of no value to the reader....The design of the writer, who is no more than the recorder of the facts detailed to him by another, has been to render the narrative as simple, and the style of the story as plain, as the laws of the language would permit'. ${ }^{8}$ Questions of authorship and voice, then, were also contested terrain in the politics of black autobiography, and modern scholars agree that they are highly complex texts that require extensive criticism whether for literary or historical purposes.

The coming of the Civil War in 1861 did not spell the end of the slave narrative. Harriet Jacobs's Incidents in the Life of a Slave Girl (published under the pseudonym 'Linda Brent'), for example, appeared in 1862. Hers, however, was one of the last to strike familiar abolitionist themes. Northern victory in the war and the abolition of slavery by constitutional 
amendment in 1865 relegated slavery (if perhaps not other forms of oppression) to the past. The abolitionist leader William Lloyd Garrison famously declared victory in the war against slavery, resigned from the American Anti-slavery Society (AAS), and ceased publication of his newspaper, the Liberator. Surprisingly, especially given their strong links to the abolitionist movement, slave narratives continued to appear in print well into the twentieth century. However, absent the urgency to bring about an end to slavery, these narratives never attracted the same notice as their antebellum predecessors and did not sound abolitionist themes as consistently or insistently. Instead postbellum narrators saw themselves as the keepers of a collective historical memory of history. Though few said so explicitly, this was a particularly important project in the late nineteenth century, as Northern and Southern whites forged a political reconciliation on a the basis of white supremacy. Louis Hughes, author of one of the more compelling postbellum narratives, rhetorically asked what the value of one man's reminiscences might be. In answer to his own question, he asserted that 'the enlightenment of each generation depends upon the thoughtful study of the history of those that have gone before, everything which tends to fullness and accuracy in that history is of value'. Hughes's narrative was intended to bring about an end to slavery but to bear witness to injustice for posterity. Truth, however, was still central to the slave narrative, even after emancipation. $^{9}$

Solomon Northup's narrative conformed in many respects to the basic conventions of the genre, but added several unusual twists. His story first reached the public in 1852 in a lengthy newspaper account of his ordeal. At the invitation of David Wilson, a writer known more for his travelogues than for his abolitionist sympathies, Northup expanded on his story in a booklength memoir, which was released in 1853. It sold well. Unlike most narrators, who were born into slavery, Northup was born free in the Saratoga-Glens Falls area of upstate New York. His status as a free man lent his narrative an element not to be found in most others. 
New to slavery himself, Northup in effect served as a guide for the uninitiated into the plantation world with the reader discovering slavery along with him in a series of steps, beginning with his being lured to Washington, D.C. to play the violin for a circus, to his kidnapping and imprisonment in one of the city's infamous slave pens, to the sea journey to the New Orleans slave market, and finally to a remote plantation on Bayou Boeuf in Louisiana.

Northup's story unfolds in a series of episodes and character studies calculated to reveal the various facets of antebellum slavery. His sketches of the enslaved are quite varied. Overall they emphasize the psychological damage inflicted by unpredictable outbursts of slave-owner violence, while simultaneously highlighting perseverance and even opposition to slavery. We meet Lew Chaney, who hatches a plot with several others to fight his way to freedom in Mexico, only to betray his companions when he became convinced it would fail. There is Eliza, the one-time concubine to a Washington-area planter, who is separated from her mixed-race children and dies of despair in Louisiana. And then there is Patsey, for whom slavery, in Northup's words, 'had shrouded her intellect in utter and everlasting darkness'. Patsey had the added misfortune to have been very beautiful--Northup described her as 'a splendid animal'...'slim and straight'. In a drama played out countless times in Southern households, she attracted the sexual attention of Mr. Epps and the bitter jealousy of Mrs. Epps. $^{10}$

Northup's sketches of whites invoke the theme of corruption even more strongly. His first master, William Ford, embodied the paternalist ideal, or as Northup wrote, 'there never was a more kind, noble, Christian man' ${ }^{11}$ Ford, however, soon ran into financial difficulties and was forced to sell Northup (while still holding the mortgage) to his plantation carpenter, Tibeats (Tibaut). In Northup's narrative, as in others, master-class paternalism is exposed as a fraud. Northup rendered Tibeats and his final master, Edwin Epps, with less subtlety. In 
different ways, the two come off as craven, brutal, and (in Epps's case) dissipated. Other whites were similarly corrupted by slavery, if perhaps less prone to violence. Armsby, the poor white man married to a free black woman, betrays Northup's trust and informs Epps of Northup's plot to get him to mail a letter for him. Again, the message is not particularly subtle: slavery corrupts whites as well as blacks. The exception was the carpenter, Bass, a Canadian who was presumably uncorrupted by slavery. While doing itinerant work in Louisiana he crossed paths with Northup, who prevailed upon him to carry a letter to government officials and friends in New York. Word eventually reached his former patron, Henry Northup, who then initiated the legal process that resulted in Solomon's release, rendered in deus ex machina fashion in the memoir. The narrative concludes with a brief epilogue narrating the failed prosecutions of the men who had kidnapped him, as well as that of James Birch, his jailer in Washington, D.C.

Twelve Years a Slave was quite successful. Northup became nationally famous and made a series of public appearances with prominent abolitionists, such as Frederick Douglass and Gerrit Smith. He starred in two different stage productions, and appears to have had a strong hand in the adaptations (both, however, were critical and commercial failures). ${ }^{12}$ The dramatic nature of Northup's story, along with its happy ending, undoubtedly appealed to Victorian narrative tastes. But other factors added to the book's commercial success. Most slave narratives were written by people who had experienced slavery in the Upper South. This is hardly surprising since to write and publish a narrative one needed to be free, and it was far easier to escape from slavery in the Upper South than it was in the Lower South. Not coincidentally, most slave narratives concluded with a harrowing tale of escape. These were usually heart-pounding scenes, which lent an air of suspense and usually functioned as the narrative's climax. They often served as a demonstration of the author's ingenuity, an implicit refutation of the notion of black cognitive inferiority. Henry Box Brown, for 
example, shipped himself from Richmond to Philadelphia in a crate. Ellen Craft disguised herself as a white, male planter accompanied by a slave (in reality her husband, William) on a trip to the North. That they escaped from the Lower South state of Georgia (their narrative was titled Running a Thousand Miles for Freedom) is the exception that proves the rule that most narrators came from the Upper South. One narrative that did not feature such a climax was Narrative of the Life of Frederick Douglass (1845). Worried that revealing his means of escape would prevent others from repeating it, he withheld details. In subsequent autobiographies, however, he revealed that he passed himself off as a free black sailor. ${ }^{13}$

Northup's narrative lacked such a climax-if anything, it was anti-climactic--but it compensated for this with several unique elements. First and foremost, audiences responded to the storyline of the free man kidnapped into slavery, and with the narrative appearing less than three years after the passage of the Fugitive Slave Act of 1850, which made it far easier to return escapees to the South, northern audiences were receptive to charges that this led to a spate of kidnappings for profit. Northup's narrative also differed in its setting. He had experienced slavery in the deepest South, in Louisiana. Although 61 percent of all slaves lived in the Lower South, a large majority of antebellum narratives were written by people who had experienced slavery in the Upper South. Northup was able to detail many things that other former-slave narrators could not, such as the domestic maritime slave trade and life on a cotton plantation. And, since he was hired out for several harvests, his is the only antebellum narrative to provide a detailed description of life on a sugar plantation, the most brutal and deadly of enterprises. It is for these reasons that historians have found Northup's narrative to be so valuable. His descriptions of plantation life in the Deep South are without parallel.

As often happened, proslavery authors questioned Northup's veracity. The line of attack was borrowed from the trial of James Birch, his jailer in Washington, D.C., whose defence argued that Northup had conspired with his kidnappers to allow himself to be abducted. As 
the plan allegedly ran, Northup would then be rescued from slavery and receive a share of his own sale price from the kidnappers. This, maintained Birch's lawyers, explained why Northup agreed to travel to Washington against advice, as well as why he and his abductors were so careful to have him secure free papers. The argument was subsequently circulated in the Democratic and Southern press. Modern historians have not given credence to these charges. Why, they ask, would Northup participate in the prosecution of his kidnappers given that a public trial might draw attention to the alleged plot? Why provide such accurate descriptions of his abductors, when it would have been safer for him if they had not been apprehended? Few even at the time apparently believed these charges, but they do highlight the importance of truth as a feature of the slave narrative. ${ }^{14}$

Northup's narrative lost its appeal as slavery receded into history. After being reprinted at least seven times between 1853 and 1900, Twelve Years a Slave went out of print for the next sixty-nine years. This lapse coincided with the appearance of the first professional academic treatments of slavery. Not surprisingly, few of these made use of the slave narratives. The most famous and influential of these early treatments was Ulrich B. Phillips's American Negro Slavery (1918), followed by his Life and Labor in the Old South (1929). Phillips, a descendant of Georgia planters who wrote at the height of the Jim Crow order, produced works that reflected the views of the Southern elite, with its 'moonlight-andmagnolias' Plantation mythology. Slave owners, he famously argued, treated their human property with kindness and slavery likened to a school for uncivilized Africans and their children. Phillips's work drew heavily on master-class sources, such as plantation records. But though aware of the existence of the slave narratives, he dismissed their validity out of hand. His reasons echoed those of the proslavery critics, charging that they 'were issued with so much abolitionist editing that as a class their authenticity is doubtful'. Interestingly, he seems to have viewed Northup's as an exception, calling his narrative 'a vivid account of 
plantation life from the underside'. Tellingly, however, Phillips never used Northup's narrative as a source on slave life, but rather to illustrate a discussion of the kidnapping of free blacks into slavery. ${ }^{15}$

Phillips's white-supremacist interpretation dominated American scholarship on slavery into the Civil Rights Era. The ground finally shifted in 1956 with the publication of Kenneth Stampp's The Peculiar Institution. Stampp provided an interpretation suitable to the times, in effect turning Phillips's on its head: slave owners were cruel, profit-minded, and exploitative. And where Phillips had excluded slave testimony from his work, Stampp's work contained many references to the narratives, though to little fanfare. Northup received brief mention in Stampp's discussion of labour routines, but even Stampp felt the need to qualify his acceptance of the narrative by reminding readers that it was written with the help of 'a Northerner' ${ }^{16}$

As the Civil Rights and Black Power Movements gained momentum in the 1960s, slave narratives moved to the centre of most scholarship. John Blassingame used them extensively in his landmark 1972 book, The Slave Community, which argued for the validity of 'black autobiographies which pass the tests commonly applied to historical sources', by which he meant the published narratives of the nineteenth century. Blassingame, however, was more circumspect regarding the narratives produced by the Federal Writers' Project in the 1930s, in part because he questioned whether elderly black Southerners spoke frankly to the project's mostly-white interviewers. ${ }^{17}$ With the appearance of Eugene D. Genovese's monumental Roll, Jordan, Roll (1972) and the simultaneous publication of a multivolume collection of WPA narratives under the title The American Slave: A Composite Autobiography, the vast majority of works on American slavery made extensive use of them. Most of these works did not attempt biography, but a few, such as those by Terry Alford, Allan D. Austin, and Melton McLaurin did. ${ }^{18}$ 
Though stressing that testimonies should never be read uncritically, it was clear that academic historians had conquered their earlier reticence regarding the veracity of both the canonical and the WPA narratives. Awareness of autobiographies written by former slaves outside the academy, however, was slim. Even today, most history undergraduates are exposed to no more than one or two of them (usually Douglass and part of Vassa), and many historians in the field are unaware of the vast amount of incidental autobiographical testimony that survives in Africa, Latin America, and the Caribbean. McQueen's initial belief that he could only tell the story he wanted through fiction is entirely understandable.

In adapting the narrative, McQueen made a series of bold and at times counter-intuitive decisions. One of these was to translate the narrative's rather spare, matter-of-fact prose to the screen. The script, for example, calls for many long periods of time without dialogue. But perhaps the most striking decision was to endow Northup with a stoic, almost opaque quality. Chiwetel Ejiofor's portrayal is powerful, but Northup's interior thoughts rarely come through. The effect is to replicate the narrative's just-the-facts prose style, which was adopted deliberately as a way to underscore the notion, as editor David Wilson expressed it, that Northup 'has strictly adhered to the truth'. ${ }^{19}$ McQueen's decision not to exercise licence and invest Northup's character with thoughts and emotions not expressed in the text signals its authenticity to viewers.

Many of McQueen's decisions resulted in a kind of tension or dissonance. Much of the film was shot on surviving plantations across Louisiana, which provided a stunningly beautiful backdrop to the exploitation and violence depicted in the screenplay. According to McQueen, he did not set out to emphasize the visual and aural beauty of Louisiana but rather went into the project without any particular aesthetic vision. Location scouting in Louisiana gave him one. 'It [the environment] was just so rich', he said, adding that 'the most beautiful, horrible things happen in the most beautiful places' (Chiwetel Ejiofor and Steve McQueen, 
interview by Terry Gross, Fresh Air, NPR, October 24, 2013). Though he did not say so, in emphasising the beauty of the setting, the film invokes, almost literally, the "moonlight-andmagnolias' mythology, a jarring contrast to the events of the story. The film's dialogue is similarly unsettling. Much of it was lifted straight from Northup's and retains what to modern ears is a rather stilted and formal Victorian tone. As with the location, the fussy formality of the dialogue contrasts with the base inhumanity depicted in the story. The Victorian dialogue also signals fidelity to the narrative, underscoring its truth by establishing a chain of evidence that runs from the film, to the narrative, and back to Wilson's guarantee of faithfulness to Northup's original story.

The film's sound editing and music are equally arresting, if perhaps not as deliberately incongruous. In the very first scene we hear an overseer instructing enslaved labours in the use of a large machete-like cane knife in a sugar field. 'Make it sing', he says as he demonstrates, and it almost does. Northup's skill as a fiddler plays a prominent role in both the narrative and the film. McQueen (and sound editor Ryan Collins) gave Northup's violin a deeply textured, at times raw and slightly scratchy sound, suitable to the backwoods setting. Northup's lively fiddle playing creates a sense of disjuncture for several scenes, including the separation of a mother and children at a New Orleans slave sale and a late-night forced square dance for the drunken and volatile Epps.

But McQueen's most striking aesthetic decision was to allow the camera to linger on a scene for a longer time than usual for a feature film. It is particularly noticeable in three of the film's most violent scenes, which all but command the audience to bear witness to slavery's brutality. The first of these takes place in the slave pen in Washington, where the jailers beat Northup repeatedly for asserting his status as a free man. For one minute and twenty-four seconds the camera does not move as we watch Birch and his henchmen lay on twenty-eight lashes. The scene late in the film where Northup and then Epps whip Patsey 
featured a single shot lasting four minutes, forty-six seconds. In contrast to the slave pen scene, the tension in this scene was broken by dialogue and the continual movement of the camera. But in perhaps the most shocking and memorable scene, one in which the carpenter Tibeats nearly kills Northup by hanging him from a tree, McQueen raised the tension to almost unbearable levels by allowing the camera to linger motionless on Northup's figure for 90 seconds. Shot from a medium-long distance without dialogue, we watch (and hear) Northup dying of strangulation. Together, these three shots last for nine minutes, ten seconds, or almost 7 percent of the film's total running time.

While the film is overall quite faithful to the narrative, there are departures from it, as well as some historical improbabilities. Most of these are likely due to McQueen's larger aesthetic and political vision for the film rather than to a cavalier attitude toward history. The plantations, for example, invariably feature white-colonnaded Greek Revival mansions that would not have been out of place in Gone With the Wind. In reality, plantation agriculture was relatively new to Louisiana's Red River parishes in the 1840 s, so the area would have had a much rougher look in Northup's time, with fewer mansions and more cabins. A few planters of Ford's status might have owned such showcases, but many of them still lived in much more modest dwellings. Smaller slaveholders like Epps could only dream of owning one. It is no accident that most of the plantation houses that appear in the film were actually located in the more established parishes along the Mississippi River. Backwoods plantations were also famously ill-kept. Many planters were so eager to make their fortunes that they never bothered to remove the stumps of felled trees and planted cotton around them. Of course, shooting the film against this kind of backdrop would have given it a very different feel and would not have set up the same ironic engagement with the moonlight-andmagnolias myth. 
The portrayal of Northup's life in New York was similarly inaccurate, but probably also the result of conscious political and aesthetic choices. His life in the film is portrayed as thoroughly bourgeois. He lives in a comfortable house, shops with his family, and tucks his children into bed at night. New York comes off as a colour-blind utopia, where shopkeepers address black men as 'Mister'. It hardly needs pointing out that in reality black New Yorkers did not enjoy equal standing, that most lived a precarious existence in the employ of whites, and that racial prejudice was as strong in New York as anywhere. Solomon Northup spent much of his pre-abduction life in vain pursuit of the propertied 'competence' idealized by Americans of the era. Relegated like most African Americans to manual labour, he rafted lumber on Lake Champlain, dug canals, performed agricultural work for local whites, and farmed barren tracts of rented land. Work often took him away from his family for weeks at a time. Like many working men of the era, Northup drank, and at one point saw a log-rafting contract voided for allegedly being drunk on the job (Northup later won a lawsuit against his employer). ${ }^{20}$ As with the dewy plantation settings, McQueen's vision of Northup's earlier life was likely calculated to set up a contrast with his life in slavery. Stressing his struggles would have made the contrast less sharp, and at worst might even have suggested a false equivalence between the racism and poverty suffered by black Northerners and enslavement in the South, a staple theme of proslavery propaganda.

More difficult is the pivotal scene in which Northup and Epps flog Patsey. The scene itself is mostly faithful to the narrative: Epps orders Northup to whip Patsey, and with no choice but to obey, he complies (in the narrative Epps threatens to flog Northup, but in the book Epps puts a gun to Northup's head). After many lashes, Northup refuses to continue, so Epps takes over. The scene is one of the most disturbing in both the book and film, with the only significant difference being that Patsey was tied to a tree for the whipping in the film but staked to the ground in the narrative. What the film does not reveal, is that Northup spent 
eight of his twelve years as a driver, that is, as a plantation foreman whose responsibility it was to maintain the pace of work. The driver's principal tool was the whip, and Northup tells us that he wore one around his neck every day and used it frequently. Drivers occupied a problematic place in the plantation hierarchy, and historians have long found it difficult to position them. The driver was, in Blassingame's words, 'the classic man caught in the middle', threatened with demotion and flogging if he failed to satisfy the master, but despised and mistrusted by the enslaved community at large. ${ }^{21}$

Northup therefore needed to explain his service as a driver without opening himself to charges of collaboration. In his narrative, Northup maintained that he mastered the art of appearing to strike without actually doing so. His fellow slaves, he claimed, would 'squirm and screech in agony, although not one of them had in fact been even grazed'. It is impossible to know whether Northup was telling the truth or whether he was trying to explain away active complicity in the slave system. Of course, even complicity must be viewed within the context of a violent coerced labour system, where refusal of an order was not an option. Indeed, for McQueen the scene is the culmination of several on the theme of Northup's will to survive. And to the extent that we see Northup making moral trade-offs for survival, the film probes some very difficult issues. But within limits, for exploring these issues too deeply - to insinuate that Northup acted as a driver to secure additional privileges, for example--might have blunted the film's larger message and inadvertently fuelled right-wing backlash and denial, in the same way that apologists for police brutality like to highlight the ‘problem’ of black-on-black violence.

Interestingly, one scene that apparently struck audiences as inauthentic (one online critic referred to it as a 'WTF moment') seems to have been based on truth. It involves the character of Mistress Shaw, played wonderfully by Alfre Woodard. The enslaved concubine of a neighbouring planter, Mistress Shaw was the de-facto plantation mistress. We see her 
hosting Patsey to a formal tea on the veranda and explaining that tolerance of Mr. Shaw's philandering was a 'small but reasonable price' to pay for the chance to escape the worst of slavery. The scene is a startling one, but it does appear in the narrative, though almost as an aside. In fact, however, publically open 'husband-and-wife' relationships between white male slaveholders and enslaved women, while always scandalous, were not uncommon, and many were tolerated locally despite their illegality. ${ }^{22}$

But more important than these rather minor issues, the film never addresses the slave narrative's long, contested history, with Northup's story taken entirely at face value. One might argue that this is a necessary corrective to a long history of discounting slave testimony as either fabrication or ventriloquism, that enslaved narrators must be believed. And since the 1970s, academic historians would certainly agree. But something about this runs counter to one of the principal articles of the historian's faith, that no source can reveal objective historical truth, and that all must be critically analysed. Is it possible to convey such a criticism in a commercial feature film? Almost surely not, but this is an idle quibble, a symptom of what the Germans call Berufskrankheit, or the compulsion to let professional concerns infect other areas of life. For now, Twelve Years a Slave stands as the best cinematic interpretation of American slavery.

The film's true impact will take time to evaluate, but one legacy appears to have been to help dispel the 'unthinkability' of autobiographical testimony by enslaved people. In the few short years since the film's release, a host of slavery-themed films have come out, and several of these have taken a biographical approach of some description. Nate Parker's Birth of a Nation (2016) examined the famous 1831 revolt led by Nat Turner in Virginia, and the same year saw a remake of the classic television miniseries Roots. The latter, of course, was still 'faction', but this time producers employed historians as consultants. Another legacy, however, seems to be a sense among at least some African Americans that too many films 
about slavery have been made recently. The films' focus on past oppression, they charge, distracts from present day action. The future of enslaved biography on film is unclear, but the debate does serve as a reminder that, to paraphrase Faulkner, the past is never past. ${ }^{23}$

Ajoe, Nicole N. 2014. 'Caribbean Slave Narratives', in John Ernest (ed.), The Oxford Handbook of the African American Slave Narrative (New York: Oxford University Press), 362-70.

Alford, Terry. 1977. Prince Among Slaves: The True Story of An African Prince Sold into Slavery in the American South (New York: Harcourt, Brace, Jovanovich).

Andrews, William L. 1988. To Tell a Free Story: The First Century of Afro-American Autobiography, 1760-1865 (Urbana: University of Illinois Press).

Austin, Allan D. 1984. African Muslims in Antebellum America: A Sourcebook (New York: Garland, 1984).

Ball, Charles. 1970. Fifty Years in Chains (Reprint edn.; New York: Dover Publications).

Blassingame, John W. 1979. The Slave Community: Plantation Life in the Antebellum South (Revised and Enlarged edn.; New York: Oxford University Press).

Blassingame, John W. 1985. 'Using the Testimony of Ex-Slaves: Approaches and Problems', in Charles T. Davis and Gates, Henry Louis, Jr. (eds.), The Slave's Narrative (New York: Oxford University Press).

Blassingame, John W. (ed.). 1977. Slave Testimony: Two Centuries of Letters, Speeches, Interviews, and Autobiographies (Baton Rouge: Louisiana State University Press).

Blight, David W. 2007. A Slave No More: Two Men Who Escaped to Freedom, Including their own Narratives of Emancipation (Orlando: Harcourt).

Brown, Henry Box. 1849. Narrative of Henry Box Brown... (Boston: Brown \& Stearns). 
Buchanan, Kyle. 2013. 'The Toughest Scene I Ever Wrote', online at http://www.vulture.com/2013/12/john-ridley-12-years-a-slave-toughest-scene-iwrote.html, accessed September 25, 2017.

Carretta, Vincent (ed.). 1995. Olaudah Equiano: The Interesting Narrative and Other Writings (New York: Penguin).

Carretta, Vincent (ed.). 2004. Unchained Voices: An Anthology of Black Authors in the English-Speaking World of the 18th Century (Expanded edn., Lexington: University Press of Kentucky).

Craft, William. 1860. Running a Thousand Miles for Freedom; Or, the Excape of William and Ellen Craft from Slavery (London: William Tweedie).

Cugoano, Ottobah. 1825. 'Narrative of the Enslavement of Ottobah Cugoano, a Native of Africa; published by himself, in the Year 1787', in Thomas Fisher (ed.), The Negro's Memorial; or, Abolitionist's Catechism; by an Abolitionist (London: Hatchard \& Co.), 120-27.

Curtin, Philip D. (ed.). 1967. Africa remembered: narratives by West Africans from the era of the slave trade (Madison: University of Wisconsin Press).

Davis, Charles T. and Gates, Henry Louis, Jr. (eds.). 1985. The Slave's Narrative (New York: Oxford University Press).

Davis, Natalie Zemon. 2000. Slaves on Screen: Film and Historical Vision (Cambridge: Harvard University Press).

'Room For Opinion: Do Dramas about Slavery Stifle Tales of Black Lives Now?' New York Times, online edition, June 6, 2016.

Douglass, Frederick. 1845. Narrative of the Life of Frederick Douglass (Boston: Anti-Slavery Office).

Ernest, John. (ed.). 2014. The Oxford Handbook of the African American Slave Narrative (New York: Oxford University Press). 
Escott, Paul D. 1985. 'The Art and Science of Reading WPA Slave Narratives', in Charles T. Davis and JR. Gates, Henry Louis (eds.), The Slave's Narrative (New York: Oxford University Press), 40-47.

Fisch, Audrey (ed.). 2007. The Cambridge Companion to the African American Slave Narrative (Cambridge: Cambridge University Press).

Fiske, David, Brown, Clifford W., and Seligman, Rachel. 2013. Solomon Northup: The Complete Story of the Author of Twelve Years a Slave (Santa Barbara: Praeger).

Genovese, Eugene D. 1972. Roll, Jordan, Roll: The World the Slaves Made (Vintage edn.; New York: Random House).

Hammon, Briton. 1760. A Narrative of Uncommon Sufferings, and Surprizing Deliverance of Briton Hammon, a Negro Man... (Boston: Green \& Russell).

McLaurin, Melton A. 1991. Celia, a Slave: A True Story (Athens: University of Georgia Press).

Northup, Solomon. 2017. Twelve Years a Slave: Authoritative Text (Norton Critical Editions; New York: W.W. Norton \& Co.).

Phillips, Ulrich B. 1918. American Negro Slavery (Baton Rouge: Louisiana University Press).

Phillips, Ulrich B. 1929. Life and Labor in the Old South (Boston: Little, Brown, and Company).

Rawick, George P. (ed.). 1971-1979. The American Slave: A Composite Autobiography 41 vols. (Westport, CT: Greenwood Press).

Rothman, Joshua D. 2003. Notorious in the Neighborhood: Sex and Families across the Color Line in Virginia, 1787-1861 (Chapel Hill: University of North Carolina Press).

Stampp, Kenneth M. 1956. The Peculiar Institution: Slavery in the Antebellum North (New York: Vintage).

Trouillot, Michel-Rolph. 1995. Silencing the Past: Power and the Production of History (Boston: Beacon). 
Woolfork, Lisa. 2009. Embodying American Slavery in Contemporary Culture (Urbana: University of Illinois Press).

Wright, Donald R. 1981. 'Uprooting Kunta Kinte: On the Perils of Relying on Encyclopedic Informants', History in Africa, 8 (1), 205-17.

${ }^{1}$ Trouillot,1995, p. 73.

${ }^{2}$ For discussions of slavery in film, see Davis, 2000; Woolfork, 2009.

${ }^{3}$ Wright, 1981.

${ }^{4}$ Blight, 2007, pp. 11-12; Escott, 1985, p. 40.

${ }^{5}$ Hammon, 1760; Carretta (ed.), 1995; Carretta, 2004. On Hammon's as the 'first' slave narrative, see Davis and Gates, 1985, p. xix. The best survey of slave narratives as literary and historical sources is Davis and Gates (eds.), 1985. See also Andrews, 1988; Blassingame (ed.), 1977); Philip D. Curtin (ed.), 1967); Ernest (ed.), 2014; Fisch (ed.), 2007.

${ }^{6}$ Ajoe, 2014, p. 362; Blight, 2007, pp. 11-12.

${ }^{7}$ Douglass, 1845 , pp. 65-66.

${ }^{8}$ Ball, 1970, pp. iii, xi.

${ }^{9}$ Hughes, 1897, p. 3.

${ }^{10}$ Northup, 2017, p. 108.

${ }^{11}$ Northup, 2017, p. 56.

${ }^{12}$ Fiske, Brown, and Seligman, 2013, pp. 117-23. 
${ }^{13}$ Brown, 1849; Craft, 1860; Douglass, 1845.

${ }^{14}$ Fiske, Brown, and Seligman, 2013, p. 139.

${ }^{15}$ On the publishing history of Twelve Years a Slave, see Fiske, Brown, and Seligman, 2013, pp. 167-169; Phillips, 1929, p. 219; Phillips, 1918, p. 444.

${ }^{16}$ Stampp, 1956, p. 74.

${ }^{17}$ Blassingame, 1979, p. xii; Blassingame, 1985, pp. 84-88.

${ }^{18}$ Genovese, 1972; Rawick (ed.), 1971-1979; Alford, 1977; Austin, 1984; McLaurin, 1991.

${ }^{19}$ Northup, 2017, p. 13.

${ }^{20}$ Fiske, Brown, and Seligman, 2013, pp. 27-41.

${ }^{21}$ Blassingame, 1972, p. 258.

${ }^{22}$ Buchanan, 2013. On interracial relationships, see Rothman, 2003.

${ }^{23}$ New York Times, June 6, 2016. 